\title{
Multiple mating and paternity determinations in domestic swine (Sus scrofa)
}

\author{
Ulises AGUILERA-REYES ${ }^{\mathrm{a} *}$, Guadalupe ZAVALA-PÁRAMO ${ }^{\mathrm{c}}$, \\ Juan José VALDEZ-ALARCóN ${ }^{c}$, Horacio CANO-CAMACHO ${ }^{c}$, \\ Georgina I. GARcíA-LóPEZ ${ }^{\mathrm{a}}$, Nazario PESCADOR-SALAS ${ }^{\mathrm{b}}$
}

\author{
${ }^{\text {a }}$ Biotic Resources Research Centre, Faculty of Sciences, Autonomous University \\ of the State of Mexico, Instituto Literario 100 Oriente, CP 50000, Toluca, Estado de México, Mexico \\ ${ }^{\mathrm{b}}$ Zootecnics and Veterinary Faculty, Autonomous University of the State of Mexico, Mexico \\ ${ }^{\mathrm{c}}$ Biotechnology Studies Mutidisciplinary Centre, Zootecnics and Veterinary Faculty, \\ University of Michoacan, San Nicolas de Hidalgo, Mexico
}

(Received 3 August 2004 - Accepted 12 May 2006)

\begin{abstract}
When a sow copulates with different boars, fecundation can take a slant towards the best quality male, which should have a more competitive ejaculation. In polyandric animals, genitals can be more elaborated and be an indication of spermatic competence or cryptic female choice. In swine, the male and female genital morphologic characteristics are evidence that allow the assumption of spermatic competence and cryptic choice in this species. In order to prove this hypothesis, the paternity of a group of 18 York/Landrace $(\mathrm{Y} / \mathrm{N})$ sows was determined; these sows copulated with three boars: Yorkshire $(\mathrm{Y} / \mathrm{Y})$, York/Landrace $(\mathrm{Y} / \mathrm{N})$ and Landrace $(\mathrm{N} / \mathrm{N})$. The three boars had the same probability of copulating in the first, second, and third place with each of the sows in an interval of 12 hours between each mating. Four polymorphic molecular markers were used in order to establish the paternity (S0033, S0035, S0036 and S0037). The results indicate that the Y/N male had $85.59 \%$ of paternity, $\mathrm{Y} / \mathrm{Y}$ male $8.8 \%$ and $\mathrm{N} / \mathrm{N} 5.8 \%$. According to the mating order, when the $\mathrm{Y} / \mathrm{N}$ male copulated in the first place, it had $89.6 \%$ paternity (26 offspring; 12 males; $46.15 \%$ and 14 females, $53.85 \%$ ) when it copulated in the second place, it had $100 \%$ paternity ( 8 offspring; 4 males, $50 \%$ and 4 females, $50 \%$ ), and when it mated in the third place, it had $77.41 \%$ paternity ( 22 offspring; 13 males, $59.1 \%$ and 9 females, $40.9 \%$ ). Sows in estrus participated in the removal of semen from four sows minutes after the copula by female-female mating. The multiple mating allowed certain competence among the ejaculation and the possibility of the female to slant the paternity towards the heterozygote male with higher genetic variability, compared to the homozygote male (Y/Y and $\mathrm{N} / \mathrm{N})$.
\end{abstract}

multiple mating / cryptic female choice / microsatellites / sows

\footnotetext{
*Corresponding author: uar@uaemex.mx
} 
Résumé - Accouplements multiples chez les truies domestiques (Sus scrofa) et détermination de la paternité de leur progéniture. Lorsqu'une femelle s'accouple avec différents mâles celle-ci peut biaiser la fécondation en favorisant l'éjaculat du mâle qui a le meilleur potentiel. Chez les animaux polyandres, les organes génitaux peuvent être plus complexes et permettre que les spermatozoïdes de mâles différents interagissent entre eux (compétition spermatique) et/ou avec le tractus reproducteur de la femelle (choix cryptique). Chez le porc, les caractéristiques morphologiques des organes reproducteurs - mâles et femelles - suggèrent l'existence de compétition spermatique et de choix cryptique des femelles. Cette hypothèse a été étudiée en déterminant la paternité de la progéniture d'un groupe de 18 femelles York/Landrace (Y/N) qui se sont accouplées successivement avec trois mâles de race : Yorkshire $(\mathrm{Y} / \mathrm{Y})$, York/Landrace $(\mathrm{Y} / \mathrm{N})$ et Landrace $(\mathrm{N} / \mathrm{N})$. Les trois mâles ont eu la même probabilité de s'accoupler en première, deuxième et troisième place avec chacune des femelles et avec un écart de 12 heures entre chaque accouplement. Pour établir la paternité, quatre marqueurs moléculaires polymorphiques (S0033, S0035, S0036 et S0037) ont été utilisés. Les résultats ont montré une paternité de 85,29 \% pour le mâle $\mathrm{Y} / \mathrm{N}, 8,8 \%$ pour le mâle $\mathrm{Y} / \mathrm{Y}$ et $5,8 \%$ pour le mâle N/N. Si on considère l'ordre d'accouplement, on attribue $89,6 \%$ de la paternité au mâle Y/N (26 descendants; 12 mâles et 14 femelles) lorsqu'il est le premier, $100 \%$ (8 descendants; 4 mâles et 4 femelles) quand il est le deuxième et 77,41 \% (22 descendants; 13 mâles et 9 femelles) quand il est le troisième à s'accoupler. Les truies en oestrus se sont accouplées entre elles, participant ainsi à l'élimination du sperme chez quatre truies dans les minutes qui ont suivi leur accouplement. Les accouplements multiples ont permis une certaine compétition entre les spermatozoïdes issus de différents mâles et les femelles ont favorisé la paternité du mâle hétérozygote, assurant ainsi une meilleure variabilité génétique par rapport aux mâles homozygotes ( $\mathrm{Y} / \mathrm{Y}$ et N/N).

accouplements multiples / choix cryptique de la femelle / microsatellites / porc

\section{INTRODUCTION}

Feral male pigs (sus scrofa) are usually solitary, but during the mating season they compete actively for the access to sows in estrus $[13,18,35]$. In swine farms, it is sometimes observed that when sows in estrus are put together with males for mating purposes, some of the latter do not show any interest in some females, and also, some females apparently do not allow some males to mate them. It has also been seen that some males need to perform a larger number of persuasions in order to copulate [30-32].

Males and females follow different strategies to maximize their reproductive success; with males, the success rests on the number of females it can have offspring with. In most of the social animal groups, females mate with more than one male during a sexual cycle. This is the reason why females promote extra-couple mating with more attractive males than those they have mated with [24]. It has been documented that the female not only practices the selection of a couple at a behavioral level, but also that it continues after mating in the female's reproductive tract at a physiological and behavioral level. This will allow the female to influence the possibilities of success of the ejaculations from different males when fertilizing their ovum [15]. Studies on multiple paternities have been documented on mammals from the use of molecular markers, as microsatellites [16, 17]. The fact that the female can slant the paternity towards one of the males she has mated with can be advantageous if this is reflected in the genetic quality improvement of offspring; this strategy is known as cryptic choice [10].

The sow's reproductive tract is frequently complex and hostile toward sperm cells. It has been suggested that the reason why the female mates with more than one male is that sperm from different males compete in its reproductive tract. Some ways the sow can slant the sperm from different males are present when the female seeks to mate with another male immediately after having mated with a low quality male. She can use much more complex physiological mechanisms, such as 
avoiding embryo implantation in the case of mammals, expelling most of the sperm it has received, not ovulating, not laying eggs or laying fewer eggs than usual, aborting, ending the mating prematurely, etc. All of these mechanisms have been seen in at least one species.

Experimental evidence also demonstrates that the courtship during mating is useful to increase the egg fertilization probability from the male that did it. In the American butterfly (Utheteisa ornatrix), females slant paternity towards the older male they mated with $[4,5,10-12,15]$.

In the male, the morphologic characteristics of the penis, such as length (45 to $50 \mathrm{~cm}$ ), the spiral in the glans (from two to three spirals) and the secretion from the vaginal tap (from 40 to $60 \mathrm{~g}$ ), as well as the complexity of the female reproductive tract such as a long cervix $(10 \mathrm{~cm})$ with a ring with a left thread shape forming a spiral, with two flexible and mobile uterine horns, the reduction of the neck's light in the uteru-tubaric union in the sow, according to Eberhard [10] these are evidence that allow the supposition of sperm competence and cryptic choice existence in this species. In a study on swine [1], the pre-mating choice from the sow in estrus was determined, in addition to the mating behavior in the Yorkshire, York/Landrace and Landrace breeds. It was found that the females show a pre-mating choice towards the $\mathrm{Y} / \mathrm{N}$ male. This very male presents a preference towards "nose-vaginal contacts" displayed when the female is presented to the male for mating.

This study was performed using microsatellites as molecular markers in order to prove if the females' pre-mating choice slant is correlated to paternity.

\section{MATERIALS AND METHODS}

\subsection{Area of study}

The laboratory study to determine the paternity in swine was developed at the
Multidisciplinary Centre of Biotechnology of the Faculty of Veterinary and Zootechny Medicine of the Michoacán University of San Nicolás de Hidalgo, and the field work at the Zootechnic Pen of the Faculty of Veterinary and Zootechny Medicine of the Autonomous University of the State of Mexico.

\subsection{Swine genetic quality determination}

Boars were acquired from three swine farms; one located in the Municipality of Naucalpan, State of Mexico, the other at the Zootechny Pen of the Faculty of Veterinary and Zootechny Medicine of the Autonomous University of the State of Mexico, and the third one located in the city of Querétaro, State of Querétaro. The genetic quality of the breed was determined by means of their purity registers. A Landrace $(\mathrm{N} / \mathrm{N})$, Yorkshire $(\mathrm{Y} / \mathrm{Y})$ and a hybrid Yorkshire/Landrace ( $\mathrm{Y} / \mathrm{N})$ males were acquired. The age of the pigs was one year; the weight oscillated between 180 and $200 \mathrm{~kg}$, with the $\mathrm{N} / \mathrm{N}$ the heaviest and the $\mathrm{Y} / \mathrm{Y}$ the lightest. Eighteen healthy F1 Yorkshire/Landrace $(\mathrm{Y} / \mathrm{N})$ sows were used, the females weight varied from 90 to $110 \mathrm{~kg}[19,20]$. A semen evaluation was performed on each male in order to determine their sperm genetic viability, as well as the semen count per milliliter. The semen was collected using the gloved-hand technique [6,34]. The semen standard parameters were evaluated macroscopically as well as microscopically. Motility was determined visually under an optic microscope. The percentage of morphologically abnormal sperm was performed with Neubauer chamber counting. In order to verify the real sperm viability, each boar was mated with a sow; their fertility was proven [28]. 


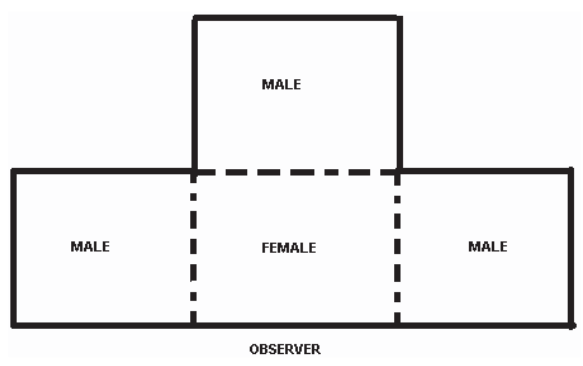

Figure 1. Copula experimenting area.

\subsection{Multiple mating}

Estrus in females was detected according to the reported characteristics $[3,21]$. In order to register the choice and premating behavior, each sow was located in the experimentation area (Fig. 1), which consisted in a closed square pen of $3 \mathrm{~m}^{2}$. Each wall had a $1 \mathrm{~m}^{2}$ window to the floor, delimited by steel bars each $20 \mathrm{~cm}$, which allowed olfactory, visual, auditory and partially tactile communication of each sow with the boars, which were located in pens attached to that of the sow. Males were systematically rotated from their pens after each female pre-mating choice in order to avoid slants in the sows behavior due to the place and not to the boar. The pigs pre-mating behavior register was performed by means of the "mate focal" sampling $[2,25]$. Each pre-mating behavioral register event lasted for 15 minutes, starting with the introduction of the female into the experimentation area. The female pre-mating choice of the males was determined by registering the time when the sow was in contact with the barrier where the males were located, as well as with the frequency of the approaching conducts, sniffing and nose-nasal contact displayed from the females to the males. This procedure was performed following the ethogram according to what was reported by Blackschaw [7]. For swine courtship the following was observed: approaching,
Table I. Copula order of males with females.

\begin{tabular}{lccccc}
\hline \multicolumn{3}{c}{ Male mating order } & \multicolumn{3}{c}{ Females } \\
\hline $\mathrm{Y} / \mathrm{Y}$ & $\mathrm{Y} / \mathrm{N}$ & $\mathrm{N} / \mathrm{N}$ & 1 & 2 & 3 \\
$\mathrm{Y} / \mathrm{Y}$ & $\mathrm{N} / \mathrm{N}$ & $\mathrm{Y} / \mathrm{N}$ & 4 & 5 & 6 \\
$\mathrm{Y} / \mathrm{N}$ & $\mathrm{Y} / \mathrm{Y}$ & $\mathrm{N} / \mathrm{N}$ & 7 & 8 & 9 \\
$\mathrm{Y} / \mathrm{N}$ & $\mathrm{N} / \mathrm{N}$ & $\mathrm{Y} / \mathrm{Y}$ & 10 & 11 & 12 \\
$\mathrm{~N} / \mathrm{N}$ & $\mathrm{Y} / \mathrm{Y}$ & $\mathrm{Y} / \mathrm{N}$ & 13 & 14 & 15 \\
$\mathrm{~N} / \mathrm{N}$ & $\mathrm{Y} / \mathrm{N}$ & $\mathrm{Y} / \mathrm{Y}$ & 16 & 17 & 18 \\
\hline
\end{tabular}

Code: York male $\mathrm{Y} / \mathrm{Y}$; York/Landrace male $\mathrm{Y} / \mathrm{N}$; Landrace male N/N.

sniffing, nose-nasal contact, vagina sniffing, nibbling, teeth clattering, vocalizations, prepuce secretions and salivation. For the register of mating conducts, each female was placed with the corresponding male according to the mating order (Tab. I). Mating conducts displayed by the males were attempts of mounting; mounting with intromission, copula, and some pre-mating conducts were also registered. The time of the copula was registered, as well as the deposition of the vaginal tap (gelatinous secretion deposited by the male during ejaculation) [1].

After mating, sows were placed in other pens, along with other females in proestrus and estrus, this is when the femalefemale interactions were registered.

\subsection{Paternity determination}

Blood samples were taken from the male, female and their offspring using sterile lancets. In order to avoid human DNA contamination of the simples, latex gloves were used. The blood samples were collected in sterile gauze and were kept safe inside individual sealed plastic bags. A phenol chloroform technique was used to extract the DNA from the pigs [23]. In order to determine paternity, 4 polymorphic swine microsatellites were selected as molecular markers (Tab. II). The main chain oligonucleotides of each molecular 
Table II. Characteristics of the microsatellites used as molecular markers.

\begin{tabular}{lccc}
\hline First & Sequence $\left(5^{\prime}-3^{\prime}\right)$ & References & Size $(\mathrm{pb})$ \\
\hline S0033 & TGGGGTTCACTGGTTTCAACT & Brown and & $207,211,215,217$, \\
& CTGGAACCGTTAGGTCAGAAA- & Archibald [9] & $219,221,223,225$ \\
S0035 & GGCCGTCTTATACTCTCAGCATA & Brown and & $178,180,181,182$, \\
& CCAAATAAACAGCAGGCAGCCT & Archibald [9] & $183,184,185,186$ \\
\multirow{2}{*}{ S0036 } & AGTGACGTGAGGGTCTGCTCCTC & Brown et al. [8] & $114,118,120,122$, \\
& ATGGACGGTGGATTCACAGCC & & $124,126,128,130$ \\
S0037 & TCTCTGAGGTGATTGTGCATG & Brown et al. [8] & $132,136,138$, \\
& GTTCAATCCCTGATGGTCT & & $140,142,144$ \\
\hline
\end{tabular}

marker were synthesized using the 6-FAM fluorescent marker by Applied Biosystems in the United States, whereas the secondary sequences with the same initiators were synthesized by Invitrogen.

\subsection{Conditions of RCP}

From the following components, $15 \mu \mathrm{L}$ of reaction blend were used: $1.5 \mu \mathrm{L}$ of buffer $10 \mathrm{X} ; 1.5 \mu \mathrm{L}(25 \mathrm{mM})$ of $\mathrm{MgCl}_{2}$; $1.5 \mu \mathrm{L}$ of dNTP mixture $(250 \mu \mathrm{M}$ of each dNTP); $0.5 \mu \mathrm{L}(5 \mu \mathrm{M})$ of each initiator blend; $0.20 \mu \mathrm{L}$ of polymerase taq, $\left(50 \mathrm{ng} \cdot \mu \mathrm{L}^{-1}\right)$ genomic DNA, distilled and de-ionized water was added in order to obtain a final blend of $15 \mu \mathrm{L}$.

The samples were amplified using a J.M Research thermocycler for 60 samples, under the following conditions: for the S0033: 30 cycles of $1 \mathrm{~min}$ at $92^{\circ} \mathrm{C}, 30 \mathrm{~s}$ at $58{ }^{\circ} \mathrm{C}, 1 \mathrm{~min}$ at $72{ }^{\circ} \mathrm{C}$, followed by a final extension of $5 \mathrm{~min}$ at $72{ }^{\circ} \mathrm{C}$. For the S0035: 30 cycles of $30 \mathrm{~s}$ at $92{ }^{\circ} \mathrm{C} ; 5 \mathrm{~min}$ at $65{ }^{\circ} \mathrm{C}$, followed by a final extension of 5 min at $65{ }^{\circ} \mathrm{C}$. For the S0036: 30 cycles $30 \mathrm{~s}$ at $92{ }^{\circ} \mathrm{C}, 5 \mathrm{~min}$ at $65^{\circ} \mathrm{C}$ followed by a final extension of $5 \mathrm{~min}$ at $65^{\circ} \mathrm{C}$. For the S0037: 30 cycles $1 \mathrm{~min}$ at $92{ }^{\circ} \mathrm{C}, 30 \mathrm{~s}$ at $55^{\circ} \mathrm{C}, 1 \mathrm{~min}$ at $72{ }^{\circ} \mathrm{C}$, followed by a final extension of $5 \mathrm{~min}$ at $72{ }^{\circ} \mathrm{C}$. The amplified sample was verified by placing $4 \mu \mathrm{L}$ of the amplified product in an agarose gel $2 \%$ and it was read in a transluminator.

\subsection{Preparation and running of the samples in the GeneScan}

In each eppendorf tube $0.5 \mathrm{~mL}, 12 \mu \mathrm{L}$ of de-ionized formamide, $15 \mu \mathrm{L}$ of GeneScan-350, and $1 \mu \mathrm{L}$ of each amplified product were mixed. The samples were run by capillary electrophoresis with fluorescent marking in an ABI PRISM 310 Genetic Analyzer [14].

\section{RESULTS}

Each male copulated with 18 sows, from which 166 piglets were born. The genetic analyses with the S0033, S0035, S0036, S0037 molecular markers were useful to determine the paternity of 68 piglets. The S0033 marker did not amplify hence; it was not useful as a marker.

From the 68 established paternity piglets, $85.29 \%$ were from the $\mathrm{Y} / \mathrm{N}$ male, the $\mathrm{Y} / \mathrm{Y}$ male got $8.8 \%$, while the $\mathrm{N} / \mathrm{N}$ male got $5.8 \%$ (Tab. III).

From the 18 copulated females by the three males, it was only possible to determine the offspring from 10 females. The paternity was of 58 piglets for the $\mathrm{Y} / \mathrm{N}$ male, 6 piglets for the $\mathrm{Y} / \mathrm{Y}$ male and 4 piglets for the N/N male (Tab. IV).

According to the mating order, when the $\mathrm{Y} / \mathrm{N}$ male copulated in the first place it got $89.6 \%$ of the paternity (26 offspring; 12 males, $46.15 \%$ and 14 females, 
Table III. Paternity percentages of the three males.

\begin{tabular}{lcccc}
\hline No. of offspring & $\mathrm{Y} / \mathrm{Y}$ male & Y/N male & $\mathrm{N} / \mathrm{N}$ male & Undetermined \\
\hline 166 & $6(8.8 \%)$ & $58(85.29 \%)$ & $4(5.8 \%)$ & 98 \\
\hline
\end{tabular}

Table IV. Paternity by copula order.

\begin{tabular}{llcccccc}
\hline Female & \multicolumn{3}{c}{ Copula order } & No. of offspring & Y/N male & Y/Y male & N/N male \\
\hline 1 & $\mathrm{Y} / \mathrm{Y}$ & $\mathrm{Y} / \mathrm{N}$ & $\mathrm{N} / \mathrm{N}$ & 12 & 8 & 0 & 0 \\
5 & $\mathrm{Y} / \mathrm{Y}$ & $\mathrm{N} / \mathrm{N}$ & $\mathrm{Y} / \mathrm{N}$ & 13 & 6 & 2 & 1 \\
6 & $\mathrm{Y} / \mathrm{Y}$ & $\mathrm{N} / \mathrm{N}$ & $\mathrm{Y} / \mathrm{N}$ & 11 & 4 & 1 & 1 \\
7 & $\mathrm{Y} / \mathrm{N}$ & $\mathrm{Y} / \mathrm{Y}$ & $\mathrm{N} / \mathrm{N}$ & 14 & 8 & 0 & 0 \\
9 & $\mathrm{Y} / \mathrm{N}$ & $\mathrm{Y} / \mathrm{Y}$ & $\mathrm{N} / \mathrm{N}$ & 10 & 6 & 0 & 0 \\
11 & $\mathrm{Y} / \mathrm{N}$ & $\mathrm{N} / \mathrm{N}$ & $\mathrm{Y} / \mathrm{Y}$ & 9 & 6 & 1 & 0 \\
11 & $\mathrm{Y} / \mathrm{N}$ & $\mathrm{N} / \mathrm{N}$ & $\mathrm{Y} / \mathrm{Y}$ & 8 & 6 & 1 & 0 \\
12 & $\mathrm{Y} / \mathrm{N}$ & $\mathrm{N} / \mathrm{N}$ & $\mathrm{Y} / \mathrm{Y}$ & 10 & 0 & 1 & 0 \\
14 & $\mathrm{~N} / \mathrm{N}$ & $\mathrm{Y} / \mathrm{Y}$ & $\mathrm{Y} / \mathrm{N}$ & 11 & 9 & 0 & 1 \\
13 & $\mathrm{~N} / \mathrm{N}$ & $\mathrm{Y} / \mathrm{Y}$ & $\mathrm{Y} / \mathrm{N}$ & 9 & 5 & 0 & 1 \\
TOTAL & & & & 98 & 58 & 6 & 4 \\
\hline
\end{tabular}

Code: York male Y/Y; York/Landrace male Y/N; Landrace male N/N.

Table V. Male paternity according to mating order.

\begin{tabular}{lccccccccc}
\hline \multicolumn{3}{c}{ Male copula order } & \multicolumn{3}{c}{$\mathrm{Y} / \mathrm{Y}$} & \multicolumn{2}{c}{ Male } & \multicolumn{3}{c}{ N/N } & Total of offspring \\
1st & $2 \mathrm{st}$ & 3st & $\mathrm{m}$ & $\mathrm{f}$ & $\mathrm{m}$ & $\mathrm{f}$ & $\mathrm{m}$ & $\mathrm{f}$ & \\
\hline $\mathrm{Y} / \mathrm{Y}$ & $\mathrm{Y} / \mathrm{N}$ & $\mathrm{N} / \mathrm{N}$ & 0 & 0 & 4 & 4 & 0 & 0 & 8 \\
$\mathrm{Y} / \mathrm{Y}$ & $\mathrm{N} / \mathrm{N}$ & $\mathrm{Y} / \mathrm{N}$ & 2 & 1 & 4 & 6 & 0 & 2 & 15 \\
$\mathrm{Y} / \mathrm{N}$ & $\mathrm{Y} / \mathrm{Y}$ & $\mathrm{N} / \mathrm{N}$ & 0 & 0 & 4 & 10 & 0 & 0 & 14 \\
$\mathrm{Y} / \mathrm{N}$ & $\mathrm{N} / \mathrm{N}$ & $\mathrm{Y} / \mathrm{Y}$ & 2 & 1 & 8 & 4 & 0 & 0 & 15 \\
$\mathrm{~N} / \mathrm{N}$ & $\mathrm{Y} / \mathrm{Y}$ & $\mathrm{Y} / \mathrm{N}$ & 0 & 0 & 9 & 3 & 0 & 2 & 16 \\
$\mathrm{~N} / \mathrm{N}$ & $\mathrm{Y} / \mathrm{N}$ & $\mathrm{Y} / \mathrm{Y}$ & 0 & 0 & 0 & 0 & 0 & 0 & 0 \\
& & & 4 & 2 & 29 & 27 & 0 & 4 & 68 \\
$\%$ & & & 66.66 & 33.33 & 51.78 & 48.21 & 0 & 100 & \\
\hline
\end{tabular}

Code: York male Y/Y; York/Landrace male Y/N; Landrace male N/N. m = male, f = female.

$53.85 \%$ ), when it copulated in the second place, it got $100 \%$ of the paternity (4 males, $50 \%$, and 4 females $50 \%$ ), and finally, when it copulated in the third place, it got $77.41 \%$ of the paternity ( 22 offspring; 13 males, $59.1 \%$, and 9 females, $40.9 \%$ ) (Tab. V).

After the copula, the sows were placed in a pen for sows in estrus and there, at different times, 4 females (1, 7, 10 and 13) were copulated by other females $(10,16$, 6 ) and in all cases, the vaginal tap was expelled as well as part of the ejaculation placed by the male that had just copulated (Tab. VI).

\section{DISCUSSION}

The S0035, S0036, S0037 markers were amplified and were used to identify the 
Table VI. Effect of the female-female mating after the male mating.

\begin{tabular}{|c|c|c|c|c|c|c|}
\hline \multirow{2}{*}{\multicolumn{3}{|c|}{ Male female order }} & \multicolumn{2}{|c|}{ Male female copula } & \multirow[t]{2}{*}{ Female-female mating } & \multirow{2}{*}{$\begin{array}{l}\text { Expulsion of the seminal } \\
\text { tap and ejaculation }\end{array}$} \\
\hline & & & No. of female & Male & & \\
\hline $\mathrm{Y} / \mathrm{Y}$ & $\mathrm{Y} / \mathrm{N}$ & $\mathrm{N} / \mathrm{N}$ & 1 & $\mathrm{Y} / \mathrm{N}$ & $1 / 10$ & Yes \\
\hline $\mathrm{Y} / \mathrm{N}$ & $\mathrm{Y} / \mathrm{Y}$ & $\mathrm{N} / \mathrm{N}$ & 7 & $\mathrm{~N} / \mathrm{N}$ & $7 / 16$ & Yes \\
\hline $\mathrm{Y} / \mathrm{N}$ & $\mathrm{N} / \mathrm{N}$ & $\mathrm{Y} / \mathrm{Y}$ & 10 & $\mathrm{Y} / \mathrm{Y}$ & $10 / 6$ & Yes \\
\hline $\mathrm{N} / \mathrm{N}$ & $\mathrm{Y} / \mathrm{Y}$ & $\mathrm{Y} / \mathrm{N}$ & 13 & $\mathrm{Y} / \mathrm{Y}$ & $13 / 6$ & Yes \\
\hline
\end{tabular}

Code: Cork male $\mathrm{Y} / \mathrm{Y}$; York/Landrace male $\mathrm{Y} / \mathrm{N}$; Landrace male N/N.

paternity of $39.75 \%$ of the offspring. This paternity percentage is possible for the reason that Brown et al. [8] reported them as polymorphic microsatellites when they used them for a 10-swine sample for the S0035 and for a 13-swine sample for the S0036 and S0037 of the breeds studied here, it is probable that these microsatellites are not very specific. Marker S0033 did not amplify any sample, so it was discarded as a marker.

When microsatellites are used as molecular markers, there is not always a hundred percent paternity, for example, in a study with swine embryos [29], paternity was identified using molecular markers; TNFm2, S0082, S0097, obtaining 80\%; later, two markers were used (OPN and SW314) obtaining the paternity identification of 15 embryos more, increasing the percentage to $95.8 \%$.

The results shown in Table IV indicate a higher paternity percentage from the $\mathrm{Y} / \mathrm{N}$ male in comparison to $\mathrm{Y} / \mathrm{Y}$ and $\mathrm{N} / \mathrm{N}$ males. In this matter [29], 11 sows were inseminated using a $1 \times 10^{9}$ semen dose in a heterospermic blend from two males. It was found that from 95 embryos, 28 were from one of the boars, 63 from the other, and four could not be determined. No comments are made with respect to the male breeds; the females were Yorkshire, the same as that used in this study. One of the conclusions of that study is that the number of accessory spermatozoa was positively related to the fertilization capability, more than with the fertilization rate. In this study, these parameters were not measured and are thus points to be considered in later research.

The fact that Aguilera et al. [1] have found that before the copula, the York/Landrace females chose behaviorally $\mathrm{Y} / \mathrm{N}$ male over $\mathrm{Y} / \mathrm{Y}$ and $\mathrm{N} / \mathrm{N}$ males, indicates a certain preference towards the $\mathrm{Y} / \mathrm{N}$ male, which was reflected in the paternity despite the fact that the females copulated with the three males. The multiple mating performed by the females allows that, presumably the sows' ovules are fertilized mainly by the male with better genetic quality $(\mathrm{Y} / \mathrm{N})$ considering that the homozygote males ( $\mathrm{Y} / \mathrm{Y}$ and $\mathrm{N} / \mathrm{N})$ are of a better genetic quality. In this respect, Madsen et al. [26] comment that in adder populations where consanguinity is high, females do not choose better genetic quality males at a phenotypical level, however, when copulating with several males, they ensure to be fertilized by the one with better quality, which should present a more competitive ejaculation. It is possible that an ejaculating selection mechanism had taken place at the females' reproductive tract and was due to an unknown process; the majority of their ovules were fertilized by sperm from the male which presented more genetic variability. In this respect, Hunter [22] comments that the sperm distribution from different swine ejaculations in the female reproductive tract is not uniform, and that those that surpass the morphologic barriers 
of the utero-tubar region and isthmus and that reach the oviduct will have a higher probability of fertilizing.

According to Aguilera et al. [1] the odoriferous secretions liberated to the atmosphere by the males during the premating phase were useful as indicators for the females to slant their selection towards the $\mathrm{Y} / \mathrm{N}$ male, hence, the probable mechanism of this selection is the female hypothalamus and amygdale, facilitating the secretion of the gonadrotropinreleasing hormone $(\mathrm{GnRH})$ and the later release of the follicle stimulant (FSH) and luteinizing $(\mathrm{LH})$ hormones, favoring the sows ovulation. On the contrary, the frequent sniffing on the females' flanks could stimulate oxytocin secretion by the females' neurohypophysis, provoking caudocephalic contractions of the uterus and oviduct, facilitating spermatozoa transportation, and favoring the fertilization probabilities [27].

The gender proportions of the $\mathrm{Y} / \mathrm{N}$ male offspring were maintained to what in terms of sexual proportion was expected $(51.8 \%$ males and $48.2 \%$ females). However, the $\mathrm{Y} / \mathrm{Y}$ male paternity did vary $(66.6 \%$ male and $33.3 \%$ females), as well as for the N/N male (0\% males and $100 \%$ females). Nevertheless, the low frequency of offspring for these pigs does not allow the male and female proportions to be expressed in the expected statistical terms.

The four sows that were mated by other females provoked the expulsion of the seminal tap as well as the ejaculation, this is explained in terms of femalefemale competence, it means, the mounting females reduce the mounted females' fertilization possibilities, and presumably, increase their adequacy. Female-female sexual patterns have been observed in sheep (Ovis aries) [35], cows (Bos taurus) and Japanese macaques (Macaca fuscata) [33], as a form of intersexual competence.
We consider that the spermatic defense mechanisms in this study were low since the time lapsed between copulas by each male was of 12 hours. Hence, the slant in the larger percentage of the $\mathrm{Y} / \mathrm{N}$ male paternity could be explained in terms of feminine cryptic choice.

\section{ACKNOWLEDGEMENTS}

We would like to express our gratitude and acknowledgement to the memory of Dr. Gerardo Iglesias Sahagún, to the authorities of FMVZ-UAEMEX for their support in the Zootechnic Pen and Mariusz Janczur and Javier Manjarréz Silva for their valuable comments on the manuscript. This research has been possible thanks to the UAEM Project CODE: $1548 / 2002$.

\section{REFERENCES}

[1] Aguilera R.U., García L.G.I., Zavala P.G., Monroy V.O., Pescador S.N., Elección precopulatoria y conducta copulatoria en cerdos yorkshire, yorklandrace y landrace, Acta Zool. Mexicana (nueva serie) 22 (2006) 6373.

[2] Altman J., Observational study of behaviour: sampling methods, Behaviour 49 (1974) 227-267.

[3] Anderson L.L., Pigs, in: Hafez E.S.E. (Ed.), Reproduction in farm animals, 5th ed., Lea and Febiger, USA, 1987.

[4] Birkhead T., Moller A.P., Sperm Competition in Birds: Evolutionary Causes and Consequences, Academic Press, London, 1992.

[5] Birkhead T.R., Moller A.P., Female control of paternity, Tree 8 (1993) 100-104.

[6] Boxio P.J.L., Valoración laboratorial de la calidad seminal, correlación con la Fertilidad, Andrología 2 (1994) 25-28.

[7] Blackschaw J.K., Notes on some topics in applied animal behavior, School of Veterinary Science, Australia, 1986.

[8] Brown J.F., Hardge T., Rettenbertger G. Archibald A.L., Four new porcine polymorphic microsatellite loci (S0032, S0034, S0036, S0037), Anim. Genet. 25 (1994) 365. 
[9] Brown J.S., Archibald A.L., Two porcine polymorphyc microsatellite loci (S0033 and S0035), Anim. Genet. 26 (1995) 277-278.

[10] Eberhard W.G., Female control choice, Academic Press, New York, 1996.

[11] Eberhard W.G., Importancia de la elección femenina críptica para la etología, Etol. 6 (1998) 1-8.

[12] Eberhard W.G., Animal genitalia and female choice, in: Sherman P.W., Alcock J.A. (Eds.), Exploring animal behaviour, Sinauer Associates, Inc Massachusetts, 2001, pp. 194-201.

[13] Eisenberg J., Lockhart M., An ecological reconnaissance of Wipata National Park, Ceylon, Smithsonian Inst. Press, Washington, 1972.

[14] GeneScan Reference Guide, Chemistry reference for the ABI Prism 310 Genetic Analyzer Applied Biosystems, 2000.

[15] Gomendio M., Roldan E.R., Mechanism of sperm competition: linking physiology and behavioural ecology, Tree 8 (1993) 95-100.

[16] Gomendio M., Harcourt A.H., Roldán A.R.S., Sperm competition in mammals, in: Birkhead T.R., Moller A.P. (Eds.), Sperm Competition and sexual selection, Academic Press, San Diego, 1998, pp. 667-751.

[17] Gomendio M., Competición espermática, in: Gomendio M. (Ed.), Evolución: la base de la Biología, Manuel Soler Editor, Proyecto Sur de Ediciones, S.L. España, 2005, p. 553.

[18] Graves H.B., Behavior and ecology of wild and feral swine (SUS SCROFA), J. Anim. Sci. 58 (1984) 482-492.

[19] Foxcroft G., Aherne F., Managing The introduction of gilts to the breeding herd and optimizing gilt fertility at breeding. Breeding herd management, Preconference Workshop Allen D. Leman. Swine Conference, Minnesota, USA, 1999, pp. 15-30.

[20] Hafez E.S.E., Anatomy of female reproduction, in: Hafez E.S.E. (Ed.), Reproduction in farm animals, Lea and Febiger, Filadelfia, USA, 1987, pp. 35-64.

[21] Hughes P.E., Marley M.A., Reproducción del cerdo, Acribia, Zaragoza, España, 1984.

[22] Hunter R.F., Pre-ovulatory arrest and periovulatory redistribution of competent spermatozoa in the isthmus of the pig oviduct, J. Reprod. Fertil. 72 (1984) 203-211.

[23] Kawasaki E.S., Sample preparation from blood, cells, and others fluids, in: Innis M.A., Gelfands D.H., Snisky J.J., White T.J. (Eds.),
PCR protocols, a guide to methods and applications, Academic Press, New York, 1990 pp. 146-152.

[24] Kempenears B.G.R., Broeck M.V.D., Burke T., Broeckoven C.V., Dhondt A.A., ExtraPair paternity results for female preference for high-quality males in the blue tit, Nature 357 (1992) 494-496.

[25] Lehner P.N., Handbook of Ethological Methods, 2nd ed., Cambridge University Press, Cambridge, 1996.

[26] Madsen T., Shine R., Loman J., Hakansson T., Why do female adders copulate so frequently? Nature 355 (1992) 440-441.

[27] Mayer J.J., Brisbin I.L. Jr., A note on the scent marking behaviour of two captive reared feral boars, Appl. Anim. Behav. Sci. 16 (1986) 85-90.

[28] Popwell J.M., Flowers W.L., Variability in relationships between semen quality and estimates of in vivo and in vitro fertility in boars, Anim. Reprod. Sci. 81 (2004) 91-113.

[29] Stahlberg R., Harlizius B., Weitze K.F., Waberski D., Identification of embryo paternity using polymorphic DNA markers to assess fertilizing capacity of spermatozoa after heterospermic insemination in boars, Theriogenology 53 (2000) 1365-1373.

[30] Tanida H., Murata Y., Tanaka T., Yashimoto Y., Mounting efficiencies, courtship behavior and mate preference of boars under multisire mating, Appl. Anim. Behav. Sci. 22 (1989) 245-253.

[31] Tanida H., Hara Y., Tanaka T., Yashimoto Y., Comparisons of time spent on courtship behavior and number of mounts by boars in single and multi-sire mating, Appl. Anim. Behav. Sci. 22 (1990) 245-253.

[32] Tanida H., Miyazaki N., Tanaka T., Yoshimoto T., Selection of mating partners in boars and sows under multi-sire mating, Appl. Anim. Behav. Sci. 32 (1991) $13-21$.

[33] Vasey P.L., Female choice and inter-sexual competition for female sexual partners in Japanese macaques, Behaviour 135 (1998) 579-597.

[34] Wodzicka-Tomaszewska M., Kilgour R., Ryan M., "Libido" in the larger farm animals: A review, Appl. Anim. Ethol. 7 (1981) 203-238.

[35] Zenchak J.J., Anderson G.C., Schein M.W., Sexual partner preference of adult rams (Ovis aries) as affected by social experience during rearing, Appl. Anim. Ethol. 7 (1981) 157-167. 